\title{
$Z$ badań nad genezą przemian wyznaniowych na Śląsku Cieszyńskim w początkowym okresie kontrreformacji na przykładzie podcieszyńskiej parafii Puńców
}

Streszczenie: Wielowyznaniowe oblicze Śląska Cieszyńskiego jest jednym z elementów tworzących jego charakter Pogranicza. Stawia to pytanie o genezę tego zjawiska. Próbę uchwycenia fenomenu kształtowania się wyznaniowości na tym terenie podjęto na przykładzie dwóch wybranych wiosek - Dzięgielowa i Puńcowa, wchodzących w skład parafii w Puńcowie i znajdujących się w omawianym okresie w rękach dwóch różnych właścicieli. Analiza tekstów sprawozdań wizytacyjnych sporządzonych na potrzeby administracji kościelnej w II połowie XVII i na początku XVIII wieku nie pozostawia wątpliwości, że w procesie kształtowania się mapy wyznaniowej tych miejscowości decydującą rolę odgrywało wyznanie i zaangażowanie religijne konkretnych właścicieli dóbr.

Słowa kluczowe: Śląsk Cieszyński, czasy nowożytne, szlachta, rekatolizacja, Puńców, Dzięgielów

W ostatnich kilkunastu latach prowadzone są intensywne badania nad przemianami kulturowymi na Śląsku Cieszyńskim w czasach nowożytnych i współczesnych. Szczególne miejsce w tych badaniach zajmują prace prowadzone przez zespół utworzony i kierowany przez prof. Tadeusza Lewowickiego, szczególnie w kontekście badań nad różnymi aspektami zjawisk zachodzących na Pograniczach ${ }^{1}$.

Prace tego zespołu mają charakter wielowątkowy. Jeden z tych wątków dotyczy zagadnienia bezpośrednio mnie zajmującego, mianowicie procesów zachodzących na styku różnych wyznań. Kwestie te posiadają bogatą paletę pytań badawczych, na które próbowano już częściowo znaleźć odpowiedź.

1 Zob. np. prace: Spoteczność pogranicza - wielokulturowość - edukacja (Lewowicki i Grabowska, 1996) oraz Kwestie wyznaniowe w społecznościach wielokulturowych (Lewowicki, Różańska i Klajmon, 2002). 
Uwagę poświęcano między innymi przebiegowi kontrreformacji w II połowie XVII i - szczególnie w kontekście powstania jedynego na Górnym Śląsku Kościoła Łaski w Cieszynie - XVIII wieku. Zagadnienia kontrreformacji są jednak równie wielowarstwowe, jak i samej reformacji, badanie której na Śląsku Cieszyńskim utrudnia jednak szczupłość źródeł².

Biorąc pod uwagę wspomnianą bogatą paletę zagadnień związanych z kształtowaniem się wielowyznaniowości Śląska Cieszyńskiego, interesować mnie będzie w niniejszym artykule jeden aspekt, mianowicie pytanie o rolę panów feudalnych w wyborze i trwaniu przy określonym wyznaniu ich poddanych. Jako teren badawczy wybrałam parafię w Puńcowie położoną w pobliżu Cieszyna. W latach, które omawia artykuł, obejmowała ona dwie wioski i była zróżnicowana pod względem własnościowym. Jedna z wiosek bowiem należała do księcia, a po wymarciu cieszyńskiej linii piastowskiej przeszła w ręce Habsburgów i zarządzana była przez władze Komory Cieszyńskiej. Druga zaś znajdowała się w rękach szlachty.

Przechodząc do omówienia zaproponowanego zagadnienia, spróbuję odpowiedzieć na następujące pytania badawcze:

- Jak przedstawiała się sytuacja wyznaniowa w parafii w połowie XVII wieku?

- Kim byli ówcześni właściciele wiosek wchodzących w skład parafii?

- Czy dochodziło do zmian własnościowych, a jeżeli tak, czy zmiany te wywierały wpływ na przynależność wyznaniową mieszkańców wiosek?

Podstawę źródłową prezentowanego tekstu stanowić będą w pierwszym rzędzie sprawozdania wizytacyjne, które sporządzano na rzecz biskupów wrocławskich. Najwcześniejsze dla parafii dekanatu cieszyńskiego tego rodzaju dokumenty zachowały się z lat 1652, 1679, 1688 oraz 1697. Zostały one wydane drukiem, stanowiąc dla badaczy łatwo dostępne, nieocenione źródło informacji o stanie, w jakim znajdował się Kościół katolicki bezpośrednio po okresie reformacji (Jungnitz, 1904; Al Saheb i Pindur, 2008).

Pojawić się może w tym miejscu pytanie o wiarygodność przekazywanych przez tę kategorię źródeł informacji. Otóż, mimo że sprawozdania sporzą-

2 Literatura poświęcona historii Kościoła na Śląsku Cieszyńskim jest bardzo obszerna. Zainteresowany Czytelnik znajdzie wskazówki bibliograficzne zwłaszcza w tekstach I. Panica (Panic, 2010; Panic, 2011; Panic, 2012) oraz J. Spyry (Spyra, 2012), zamieszczonych w kolejnych tomach wydawnictwa Dzieje Ślaska Cieszyńskiego od zarania do czasów wspótczesnych (patrz bibliografia na końcu artykułu). Odnotować należy również pracę Trzysta lat tolerancji na Ślasku Cieszyńskim. W trzystulecie zatożenia kościoła Jezusowego w Cieszynie (Czyż, Gojniczek i Spratek, 2010). 
dzano na rzecz katolickich biskupów wrocławskich, z natury rzeczy wrogich protestantom, jednak - jak wykazuje lektura - były one obiektywne, nie ukrywając jakichkolwiek uchybień, które wizytujący znajdowali w parafiach. Celem wizytacji podejmowanych przez urzędników biskupich było określenie rzeczywistego stanu, w jakim w tym okresie znajdowała się cała diecezja i każda z jej parafii. Miało to umożliwić postawienie wniosków i podjęcie właściwych działań na drodze odbudowy struktur Kościoła katolickiego, jego naprawy i wreszcie - odzyskania pozycji sprzed okresu reformacji. Uzyskanie rzetelnych informacji i przekazanie prawdziwego obrazu diecezji było warunkiem sine qua non skuteczności działań administracji kościelnej. Najważniejsze z nich, w przypadku konkretnych parafii, dotyczyły odzyskiwania dawnych członków społeczności katolickiej dla Kościoła katolickiego. Jednym z widocznych tego efektów była wówczas wykazywana liczba chrztów czy ślubów w rycie katolickim.

Informacje dotyczące szlacheckich właścicieli i kolatorów miejscowości przynależnych do parafii w Puńcowie zaczerpnęłam ze źródeł genealogicznych, takich jak Materiaty genealogiczno-heraldyczne do dziejów szlachty księstwa cieszyńskiego czy Rody starého Slezska (Pilnáček, 1991-1998; Szersznik, 2004).

Ramy czasowe omawianych zagadnień zamykają się między połową XVII wieku a początkiem wieku XVIII. Okres ten wyodrębniają zgodnie wszyscy badacze dziejów Śląska Cieszyńskiego jako ten, w którym miała miejsce I faza rekatolizacji ziem dawnego Księstwa. Otwiera go śmierć ostatniej księżnej z rodu cieszyńskich Piastów i objęcie władzy przez katolickich Habsburgów, zamyka wybudowanie w Cieszynie Kościoła Łaski i początek emancypacji protestantów. Cezurę taką wyznaczają też same źródła. Pierwszy z zachowanych tekstów wizytacji biskupich pochodzi z 1652 roku, ostatni pochodzący z wieku XVII opisuje stan parafii z 1697. Dla początków XVIII wieku mamy jedynie wizytację z 1717 (która spraw wyznaniowych nie omawia) (Panic, 1994) i z 1719 roku (omówienie: Maroń, 1972). Ta z kolei przynosi wiele na ten temat cennych informacji. Cezury te uzasadnia fakt, że np. Dzięgielów znajdował się w tym czasie w rękach jednej rodziny szlacheckiej - Goczałkowskich z Goczałkowic. Rok 1719 zamyka pewien przedział w sprawozdaniach wizytacyjnych, a zarazem nie jest odległy czasowo od roku 1709, gdy protestanci uzyskali przynajmniej częściową możliwość wyznawania swojej religii. Przypuszczać można, iż ewentualne zmiany w strukturze wyznaniowej omawianego terenu nie były zbyt głębokie. Poprzez przytoczenie tekstu z 1719 roku uzyskamy interesującą perspektywę badawczą. Dane zaczerp- 
nięte z omawianego źródła powinny wykazać, czy i jak skuteczne okazały się starania Kościoła (ale i władzy świeckiej) w ciągu minionego półwiecza. Można założyć równocześnie, że uzyskany obraz status quo nie został jeszcze zniekształcony przez działania strony protestanckiej wzmocnionej po 1709 roku wsparciem króla szwedzkiego i uzyskaniem prawa do posiadania własnego proboszcza w Cieszynie, jak również przez kolejny etap działań katolickiej władzy świeckiej i duchownej, na to wzmocnienie reagującej.

Uwzględniając poczynione uwagi wstępne dotyczące źródeł i ich wiarygodności, przejdźmy do omówienia postawionego w temacie zagadnienia.

Na początek warto wskazać, że parafia w Puńcowie należy prawdopodobnie do młodszych w dawnym księstwie cieszyńskim, choć niewątpliwie posiada rodowód przedreformacyjny. Ze względu na brak wzmianki o niej w spisach świętopietrza z lat 1335 i 1447 (zob. Panic, 2010, ss. 394-400) oraz jakichkolwiek informacji w dawniejszych dokumentach proweniencji świeckiej, badacze sytuują jej powstanie około 1500 roku. Faktem dowodnym istnienia tutaj centrum religijnego jest dopiero fundowanie w 1518 roku przez księcia cieszyńskiego Kazimierza II we wsi Puńców kościoła murowanego pw. św. Jerzego, stojącego do dziś. Pierwszy dokument dotyczący parafii pochodzi z 1549 roku. Książę cieszyński Wacław III Adam określił w nim zasięg terytorialny parafii i zasady jej funkcjonowania. Wyrażenie użyte w dokumencie „jak to od starodawna ustalone maja” każe nam jednak sądzić, że zasady te ustanowił nie on sam, lecz fundator kościoła i jego poprzednik (zob. Panic i Zbylut-Jadczyk, 2018, ss. 13-15).

Około połowy XVI wieku dotychczas katolicka parafia przeszła w ręce protestantów, gdy wspomniany książę cieszyński Wacław III Adam zmienił wiarę z katolickiej na luterańską. Akatoliccy duchowni kierowali wspólnotą wiernych do około 1610 roku, gdy następca księcia Wacława III Adama i jego syn Adam Wacław dokonał kolejnej konwersji, tym razem na katolicyzm. Nieznane są nam jednak koleje losu społeczności parafialnej w dwóch kolejnych dziesięcioleciach XVII wieku. Burzliwe lata wojny trzydziestoletniej, która przetoczyła się także przez Śląsk Cieszyński, niepokoje związane ze śmiercią księcia Adama Wacława i jego syna Fryderyka Wilhelma, nie ułatwiały stabilizacji także religijnej, tym bardziej iż zdecydowaną większość ludności księstwa stanowili protestanci. Kościół przynajmniej dwukrotnie w tym czasie przechodził z rąk do rąk. Dopiero z roku 1636 pochodzi informacja o duchownych katolickich zarządzających parafią. Byli to wikary Kaspar z cieszyńskiej parafii św. Marii Magdaleny oraz od grudnia tego roku - proboszcz Mateusz Heczner. Nawet jednak fakt objęcia parafii przez sta- 
łych odtąd duszpasterzy nie oznaczał dla wiernych pełnej stabilizacji. Trzy lata później ksiądz Heczner opuścił Puńców, być może w obawie przez grozą działań wojennych. Jego następca - po trzech latach wakatu w parafii ksiądz Marcin Nisolius proboszczował równocześnie w Goleszowie, a msze sprawowali w jego zastępstwie duchowni z okolicznych miejscowości (zob. tamże, s. 15). Kiedy więc przedstawiciele biskupa wrocławskiego wizytowali parafię w połowie XVII wieku, jej stan przedstawiał się rozpaczliwie. Kierował nią komendarz Gallus Sladecius nieposiadający stałej prebendy ani inwestytury, który administrowanie przedłużył samowolnie z trzech miesięcy do czterech lat. Z nieznanych powodów nie zdołał on uporządkować spraw związanych z rachunkami kościelnymi, stąd borykał się z ogólną mizerią i w kościele brakowało wszystkiego, co potrzebne do odprawiania mszy. Wielką bolączką duszpasterza byli okoliczni predykanci, którzy chrzcili, udzielali ślubów i chowali zmarłych, najwyraźniej z pominięciem prawowitego duszpasterza. Cała społeczność wiernych była akatolicka (por. Jungnitz, 1904, ss. 21-22).

Tekst wizytacji wskazuje, że podobna sytuacja panowała w 1652 roku w większości parafii dekanatu cieszyńskiego - najczęściej biednych, pozbawionych części lub całości uposażenia zagrabionego w czasie reformacji, przeważnie akatolickich i borykających się z brakiem duszpasterzy. Pytając o możliwe tego stanu przyczyny, mówimy o trudnych latach wojennej zawieruchy, o zniszczeniu kraju i zubożeniu ludności. Wskazujemy na kryzys Kościoła katolickiego i smutne dziedzictwo konfliktów religijnych. Interesującą badawczo wydaje się kwestia samego duchowieństwa - poziomu wykształcenia, aspiracji, wreszcie: moralności posługujących wówczas księży ${ }^{3}$.

Jest jednak jeszcze jeden czynnik, jaki należy wziąć po uwagę, bo jego rola była oczywista dla spisujących teksty wizytacji. Zarówno w roku 1652, jak i w latach późniejszych konsekwentnie wskazywali na to, czy dana parafia była akatolicka oraz do kogo należał kościół, wiążąc status religijny mieszkańców z postawą właściciela wsi. Symptomatyczne jest, że w czasie pierwszej wspomnianej wizyty przedstawicieli biskupa do większości kościołów dekanatu po prostu nie wpuszczono, a przyczyną była zdecydowanie niechętna postawa panów feudalnych (por. Jungnitz, 1904, s. 30).

3 W ostatnich latach ukazały się m.in. cenne pozycje dotyczące duchowieństwa posługującego w diecezji krakowskiej (zob. Kracik, J. 2011; Dudała, H. 2015). Badań takich do tej pory nie podjęto nad duchowieństwem ówczesnego dekanatu cieszyńskiego. 
Jak wskazałam powyżej, kościół i parafia w Puńcowie w połowie XVII wieku znajdowały się w rękach katolików. Co najmniej od 1636 roku kierował nią proboszcz katolicki wybierany przez księcia cieszyńskiego, zatwierdzany przez biskupa wrocławskiego i jemu podległy, instalowany przez dziekana cieszyńskiego. W skład parafii wchodziły jednak w tym czasie dwie wsie, z których każda miała inną przynależność własnościową, a to - jak mam nadzieję wykazać - miało wpływ na kierunek ich rozwoju wewnętrznego.

Ówczesna rola panów feudalnych w kształtowaniu się wyznaniowości zwłaszcza wsi dawnego księstwa cieszyńskiego znalazła już swoje odbicie w pracach badaczy. Podkreślali oni zwłaszcza niszczycielską rolę konfliktu, jaki rozgrywał się w wielu ówczesnych parafiach pomiędzy proboszczem i panem feudalnym, najczęściej protestantem: spory o uposażenie, utrudnianie sprawowania liturgii czy pracy duszpasterskiej, a nawet bezpośrednie ataki, nie tylko słowne (zob. Machej, 2000; Pindur, 2010a, 2010b).

Puńców był od czasów wczesnonowożytnych wsią książęcą, co więcej, książę był kolatorem znajdującego się tutaj kościoła. Na historii wsi odbijało się bezpośrednio wiele decyzji władcy, także tych dotyczących spraw religijnych. Przypomnijmy w tym miejscu te najbardziej spektakularne, gdy po przejściu księcia na protestantyzm kościół około 1550 roku przejęli luteranie oraz gdy w 1610 roku decyzją następcy księcia powrócił on w ręce katolickie. Mimo pozornie komfortowej sytuacji, gdy tak kolator kościoła, jak pan feudalny byli katolikami, strona katolicka długo jeszcze po 1610 roku pozostawała w odwrocie. Winne były nie tylko wskazywane już okoliczności zewnętrzne (wojna i zniszczenia nią spowodowane), ale i wewnętrzne (ogólny kryzys Kościoła, a i kłopoty z opieką duszpasterską w samej parafii). Księżna cieszyńska Elżbieta Lukrecja - córka zmarłego księcia Adama Wacława i siostra również zmarłego księcia Fryderyka Wilhelma, sprawująca władzę w księstwie cieszyńskim od 1625 roku - nie była osobą restrykcyjną religijnie. Według jej własnych słów nie chciała sprawować władzy na sposób tyrański (Šmerda, 2004, s. 3). Mimo wydawania zarządzeń przeciwko protestantom nie dążyła do religijnej konfrontacji, również z powodów ekonomicznych, obawiając się wyludnienia i tak wyniszczonego księstwa. Ewentualne jej działania utrudnione były przez fakt, iż większość stanowisk w księstwie objęta była przez urzędników wyznania protestanckiego, absolutnie niezainteresowanych zmianą sytuacji.

Gdy w maju 1653 roku księżna Elżbieta Lukrecja zmarła jako ostatnia przedstawicielka cieszyńskiej linii Piastów, władzę w dawnym księstwie cieszyńskim objęli Habsburgowie. Byli oni katolikami, formalnie ich panowanie 
nie wiązało się z przełomem religijnym. W praktyce szybko okazało się, iż w tej sferze skończył się okres półśrodków i pokojowych rozwiązań, a rozpoczął ostry kurs na kontrreformację. Wielonarodową monarchię Habsburgów miała bowiem spajać również jedność religijna.

Już w 1653 roku powołano Komisję Religijną, która w następnym roku odebrała protestantom 50 kościołów do tej pory znajdujących się w ich rękach, wygnano z księstwa protestanckich duchownych, a w 1670 roku sprowadzono do Cieszyna jezuitów, którzy mieli zająć się skuteczną pracą duszpasterską. W krótkim czasie nawrócili oni całe rzesze mieszkańców, głównie miast. Próby wyjścia ich poza miasto nie spotkały się jednak z sukcesem. Lektura dokumentów parafialnych (głównie metryk) z Lesznej i Puńcowa wskazuje jednoznacznie na silne przywiązanie mieszkańców wsi do religii ojców. Jeszcze na początku wieku XVIII protestanci stanowili większość w lokalnej społeczności. Co więcej, w latach bezpośrednio nas interesujących, a uchwytnych źródłowo, czyli w latach 80. i 90. XVII wieku, stanowią oni trzon tzw. elity wiejskiej (wójt, podsądni, karczmarz, młynarz, bogaci chłopi, nawet kościelni), zdolnej utrudnić wykonywanie odgórnych zarządzeń. Zwłaszcza jeśli wykonania rozporządzeń mieli dopilnować protestanccy urzędnicy, sami w najlepszym wypadku do tych rozporządzeń nieprzekonani.

Druga wieś wchodząca w skład parafii - Dzięgielów - była w połowie XVII wieku szlachecka i należała do rodziny Goczałkowskich z Goczałkowic, która na drodze ożenku przejęła ją od rodziny Czelów z Czechowic (Pilnáček, 1997, s. 613-614). Od ok. 1611 roku władał nią Adam Goczałkowski, syn Hanussa, pan na Dzięgielowie, Lesznej Górnej i Nydku (Szersznik, 2004, s. 90) - akatolik z pewnością, skoro w 1652 roku nie wpuszczono wizytatorów biskupich do kościoła w Lesznej, kolatorami którego byli właśnie Goczałkowscy (por. Jungnitz, 1904, s. 30). Po śmierci Adama panem włości został w 1655 roku jego syn Karol Goczałkowski (Szersznik, 2004, s. 89). Bezpośrednie relacje duchownych katolickich zaświadczają, iż nie tylko sam był protestantem, lecz również ułatwiał to swoim poddanym i chronił ich. Dziekan cieszyński Aleksander Klaybor oskarżał go w 1671 roku, iż na zamku w Dzięgielowie gromadzi swoich chłopów celem czytania protestanckich postylli (Franek, 1939, s. 97). Nie wydaje się możliwe, by w tym okresie - przynajmniej w Dzięgielowie - mogła się rozwijać wiara inna niż protestancka.

Ponieważ zaś proboszczem w Puńcowie do 1668 roku był ks. Gallus Sladecius, którego problemy z duszpasterzowaniem poznaliśmy w 1652 roku przy okazji wizytacji biskupiej - łatwo możemy wytłumaczyć, dlaczego cała parafia była de facto ewangelicka, choć przecież kierował nią katolicki dusz- 
pasterz i podlegała katolickim strukturom kościelnym, wspieranym przez katolicką władzę świecką.

W momencie śmierci Karola Goczałkowskiego w 1676 roku jego syn Adam Wacław był małoletni, dlatego zarząd nad dobrami objęła jego matka, a żona Karola, Anna Maria Goczałkowska, rodz. Gurecka z Kornic ${ }^{4}$. Była katoliczką, w dodatku - jak przyszłość pokaże - mocno zaangażowaną w sprawy religijne parafii.

W kontekście tych uwag należy stwierdzić, iż w sprawozdaniu wizytacyjnym z 1679 roku nie zauważamy znaczących zmian w stosunku do roku 1652. Parafia jest nadal bardzo biedna i wciąż akatolicka. Być może jakiś wpływ miały na to jakieś okoliczności zewnętrzne, choć tekst o nich nie wspomina. Wydaje się, że główną winę ponosi tutaj osoba proboszcza Jakuba Chmieliny - człowieka według opisu wprawdzie uczciwego, lecz prostego, pozbawionego daru przekonywania i autorytetu (por. Jungnitz, 1904, ss. 262-263), cech niesłychanie ważnych w sytuacji, gdy pewnie nieraz przyszło mu się konfrontować $\mathrm{z}$ odmiennymi poglądami i bronić swoich racji. Brak informacji na temat panów siedzących na Dzięgielowie. Jednak wizytator w Lesznej zanotował, iż po śmierci Karola Goczałkowskiego pani dziedziczka przekazała tamtejszej parafii kapitał kościelny ulokowany za życia Karola na jego gruntach (por. Jungnitz, 1904, s. 261). Trudno jednak powiedzieć, czy pieniądze przekazano niegdyś panom w depozyt dobrowolnie, czy też zagrabili je oni w czasach reformacji, co przecież się zdarzało.

Ważne w kontekście moich rozważań informacje otrzymujemy w tekście wizytacji z roku 1688. Parafią zarządzał wtedy ks. Jan Bysonius. Nie ulega wątpliwości, że był to kapłan energiczny, który podźwignął parafię z marazmu, a wsparty działaniami z zewnątrz przyczynił się do jej dalszego rozwoju. Za jego proboszczowania w latach 1680-1700 przeprowadzono w kościele szereg remontów i zainwestowano w wyposażenie kościoła. Wiele uwagi proboszcz poświęcił pracy duszpasterskiej, skutkiem czego po latach zaniedbań rozpoczęto wreszcie katechizację wiernych, zadbano też o odpusty i procesje (por. Jungnitz, 1904, s. 581). Były to kwestie, na które wizytujący zwracali wtedy szczególną uwagę, najwyraźniej przypisując im szczególną rolę w procesie rekatolizacji wiernych.

4 Umowę przedślubną odnotowuje Szersznik (2004, s. 88) z błędną datą 1 maja 1683 (zamiast 1 maja 1653). O roli Anny Marii w zarządzaniu dobrami wspominają wizytacje z 1679 i 1688 roku. 
Szczególnie ważne dla nas są zdania dotyczące bezpośrednio panów feudalnych, w kontekście parafii w Puńcowie wypowiadane po raz pierwszy. Ze względu na ich ważkość w świetle poruszanych zagadnień pozwolę sobie je zacytować bezpośrednio: „Parafianie w większości luteranie, zaledwie 60 katolików. Byłoby ich więcej, gdyby Komora nagliła, jak nagli swoich wspomniana pani Goczałkowska, pod której [władzą] młodzież i sieroty przyłączają się do wiary katolickiej. W dobrach zaś kameralnych nawet sieroty nie stają się katolikami, ponieważ pan regent cieszyński nie dba w ogóle o dobra kameralne. Skarżą się wszędzie proboszczowie w dobrach kameralnych, iż luteranie zbierają się w lasach u predykantów" (tamże).

Tekst wskazuje na parę doniosłych kwestii, które należy tutaj podnieść. Rozwinięcie ich jednak przekracza ramy niniejszego artykułu, wymagając równocześnie dalszych studiów.

Po pierwsze, w tym okresie zmienia się struktura wyznaniowa parafii. Wśród jednolitej dotychczas ludności protestanckiej pojawiają się katolicy. Po drugie, rozkład wyznań we wsiach jest prawdopodobnie nierównomierny. Po trzecie - i to jest najważniejsze w kontekście moich rozważań - tekst wyraźnie podkreśla rolę panów feudalnych w takim, a nie innym kształtowaniu się mapy religijnej parafii. Zwiększa się udział katolików w życiu społeczności, a wynika to wyłącznie z troski dziedziczki Anny Marii Goczałkowskiej, nie ma zaś w tym zasługi władzy kameralnej ${ }^{5}$.

Na podkreślenie zasługuje kolejna kwestia. Źródło nie pozostawia wątpliwości, że szczególny nacisk kładziono na formację katolicką młodzieży i powrót do wiary katolickiej akatolickich sierot. Być może było to najłatwiejsze z możliwych działań. Dzieci pozbawione rodziców na mocy rozporządzeń cesarskich otrzymywały katolickich opiekunów i łatwo mogły powrócić do Kościoła. Ze źródeł wiemy, że Anna Maria Goczałkowska umieszczała sieroty po protestantach u jezuitów w Cieszynie, by nauczyły się podstaw nowej wiary (zob. Franek, 1939, s. 168). Wśród dokumentów parafii w Lesznej zachował się spis konwertytów sporządzony przez ówczesnego proboszcza ks. Marcina Witka. Wśród nawróconych przez niego w latach 80. i 90. XVII wieku we wsi Leszna Górna znajduje się aż 28 sierot (APLG 19, s. 150). Ciekawe, że wśród nawróconych w sąsiedniej wsi Leszna Dolna i Trzyniec, także należących do

5 Opieszałość władz Komory w wykonywaniu zarządzeń wynikała przynajmniej z dwóch powodów. Większość urzędników, będąc luteranami, nie była zainteresowana postępem rekatolizacji. Obawiano się także zmniejszenia dochodów kameralnych, spowodowanego opuszczaniem gruntów przez protestanckich poddanych (zob. Chlebowczyk, 1966, ss. 47-50; Spyra, 2012a, s. 27). 
parafii, lecz znajdujących się w rękach innych szlachciców, takich proporcji nie zauważamy. Skłonna więc jestem tutaj uznać rolę dziedziców Lesznej Goczałkowskich. Brak podobnego spisu dla parafii w Puńcowie nie pozwala dowodnie stwierdzić, czy takie procesy zachodziły w tym czasie w drugiej wsi należącej do Goczałkowskich - Dzięgielowie, choć wobec powyższych rozważań wolno domniemywać, iż tak istotnie być mogło.

I wreszcie ostatnia kwestia: w roku 1688 po raz ostatni podniesiono w Puńcowie problem predykantów i zbierania się protestanckich wiernych na nabożeństwach w lasach. Proboszcz Bysonius miał rację tylko częściowo, stwierdzając, iż problem dotyczy dóbr kameralnych. Być może różnica leżała w skali problemu. Jednakże także w dobrach szlacheckich, nawet katolickich, takie nabożeństwa się odbywały. Za przykład może służyć Kazalnica w Lesznej Górnej czy Zakamień w Nydku - miejsca znajdujące się przecież w dobrach tak zasłużonej dla postępu wiary katolickiej Anny Marii Goczałkowskiej (zob. Below i Legendź, 2009; por. Jungnitz, 1904, s. 580).

Z roku 1697 pochodzi tekst ostatniej w XVII wieku wizytacji biskupiej. Przynosi on informację, iż „w parafii wielu jest do tej pory protestantów” (Al Saheb i Pindur, 2008, s. 28). W połączeniu z wiadomością o liczbie 90 nawróconych do tej pory przez ks. Bysoniusa oraz o całkiem pokaźnej liczbie 150 wiernych, którzy przystąpili do spowiedzi wielkanocnej, uzyskujemy obraz parafii, w której wieloletnie wspólne wysiłki władzy świeckiej i duchownej odniosły skutek. Z drugiej strony, powtarzająca się skarga na regenta dóbr kameralnych, który w sporze duszpasterza z wiernymi o należności kościelne nie udziela pomocy, każe nam sądzić, że również w tym dziesięcioleciu wsparcia proboszczowi udziela głównie strona szlachecka (por. tamże, ss. 28-29).

Według wizytatora wieś Dzięgielów należy w tych latach do Anny Marii Goczałkowskiej. Być może jest to pomyłka spisującego notatkę lub wydawcy tekstu. Jak wynika z najstarszej zachowanej księgi gruntowej Lesznej Górnej i Dzięgielowa, rządził tu od około 1692 roku Adam Wacław Goczałkowski, syn Anny Marii i Karola ( $A P C$, KC 2350, k. 292). O jego zaangażowaniu w sprawy religijne wiemy z późniejszych źródeł kościelnej proweniencji. W 1719 roku fundował kościół murowany w Lesznej Górnej, przeznaczając w kolejnych latach środki także na wyposażenie i konieczne remonty świątyni. Dwaj jego synowie wybrali stan duchowny; jeden z nich, Jan Józef, został dziekanem cieszyńskim, a zmarł w 1759 roku, pełniąc posługę wśród chorych żołnierzy (Szersznik, 2004, s. 86). Fakty te wskazują na silną w rodzinie Goczałkowskich tradycję religijną i więź z Kościołem katolickim. 
Z 1719 roku pochodzi tekst kolejnej wizytacji biskupiej. Ponieważ źródło to wykracza poza ramy czasowe zakreślone w artykule, nie będę jej omawiać, przytaczając jedynie niektóre z podanych informacji. Po raz pierwszy w świetle dokumentów wizytacyjnych większość w parafii uzyskali katolicy. Było ich 200 wobec 152 ewangelików. Równocześnie jednak 15 dzieci (w tym 6 z rodzin katolickich i 9 z małżeństw mieszanych) wychowywało się w duchu ewangelickim. Wizytator odnotował też ujawnienie się 6 apostatów (por. Maroń, 1972, s. 163). Takich faktów nie odnotowano w pobliskiej Lesznej, gdzie Goczałkowski ,jako właściciel wsi bez względu na wynikające z tego straty dbał o to, aby nie było w parafii ani apostatów, ani dzieci wychowywanych w innym wyznaniu" (tamże, s. 162). Nie wiadomo, w której z dwóch wsi należących do parafii ujawniły się te zjawiska. Na podstawie uwag wizytatora poczynionych w kontekście Lesznej można domniemywać, że podobną postawę Adam Wacław Goczałkowski mógł zachowywać względem drugiej swojej wsi, a więc Dzięgielowa. Z kolei wpływy kościoła Jezusowego stojącego na przedmieściach Cieszyna mogły być większe w bliżej położonym Puńcowie. Uwagi te mają charakter poszlak, a ich weryfikacja wymaga dalszych studiów, przede wszystkim analizy metryk parafialnych rejestrujących m.in. wyznanie osób zawierających ślub oraz zmarłych. Wspomniane źródło potwierdza jednak wcześniejsze spostrzeżenia, że rodzina Goczałkowskich miała udział w procesie rekatolizacji parafii, czynnie wspierając działania proboszczów i pilnując wykonywania rozporządzeń władz.

\section{Konkluzje}

Analiza tekstów wizytacji biskupich pochodzących z II połowy XVII i początków XVIII wieku wskazuje, że w tym okresie w strukturze wyznaniowej parafii zaszły daleko idące zmiany. Społeczność wiernych, całkowicie akatolicka w 1652, stała się społecznością, w której większość w 1719 roku stanowili katolicy. Wpłynęły na to działania i rozporządzenia władz duchownych, dążących do odbudowy Kościoła katolickiego po okresie reformacji, oraz władzy świeckiej Habsburgów, którzy dążyli do uzyskania jedności wyznaniowej monarchii. Spośród wydanych rozporządzeń szczególne dla mieszkańców znaczenie miał nakaz wychowywania w katolicyzmie sierot protestanckich oraz obowiązujący przez kilka lat zakaz udzielania ślubu niekatolikom. Dokumenty parafialne, w tym metryki, wskazują wyraźnie, iż w latach 90. XVII wieku w Puńcowie wiele par ewangelickich i mieszanych wyznaniowo ugięło się wobec tego zakazu i przeszło drogę konwersji. 
Znaczenie decydujące miała jednak postawa i zaangażowanie pana feudalnego - właściciela konkretnej miejscowości. W przypadku Dzięgielowa była to katolicka od około 1676 roku rodzina Goczałkowskich, która czynnie włączyła się w proces rekatolizacji i doprowadziła do zmiany oblicza wyznaniowego wioski. Przemiany wyznaniowe w drugiej wsi należącej do parafii - Puńcowie - następowały wolniej. Władze Komory Cieszyńskiej, zarządzającej tutejszymi dobrami Habsburgów (a Puńców był ich częścią), niechętne były forsownej rekatolizacji przeprowadzanej w dobrach kameralnych, stając wobec realnego problemu ucieczek chłopów, a więc: groźby wyludnienia wsi i spadku dochodów. Na tym tle dochodziło do otwartych sporów między regentem Komory a cieszyńskim starostą ziemskim (przedstawicielem władzy świeckiej Habsburgów), jak również między regentem a jezuitami, sprowadzonymi do Cieszyna w 1670 roku i zaangażowanymi w dzieło rekatolizacji. Na brak wsparcia ze strony władz Komory skarżył się również proboszcz cieszyński Aleksander Klaybor - od 1670 roku dziekan cieszyński - a także wielu duszpasterzy ze wsi kameralnych, m.in. proboszcz puńcowski Jan Bysonius. Wśród czynników opóźniających przemiany wyznaniowe wymienić trzeba też fakt, iż zdecydowaną większość urzędników Komory stanowili wówczas protestanci. Wymiana kadry zarządzającej następowała powoli, ponieważ długo jeszcze brakowało odpowiednich kandydatów ze strony katolickiej. Z podobnych powodów trudno było wymienić we wsiach protestanckich wójtów. Katolicy, wywodzący się głównie z uboższych warstw wiejskich, niechętnie według słów regenta obejmowali ten urząd, bowiem obowiązki związane z jego wykonywaniem uniemożliwiały im pracę na roli.

Protestanci, stanowiący w społeczności parafii większość co najmniej do końca XVII wieku, według prawa traktowani byli jako członkowie Kościoła katolickiego i znajdowali opiekę duszpasterską ze strony tutejszego proboszcza. Jednak, jak zaświadcza tekst wizytacji z 1652 roku, korzystali oni wtedy raczej z posługi okolicznych predykantów. Wiadomo, że w kolejnych latach uczestniczyli w nabożeństwach odprawianych w tzw. leśnych kościołach, zaświadczonych m.in. w Lesznej Górnej, Nydku i Ustroniu. Przez dłuższy czas przynajmniej część z nich (mieszkających w Dzięgielowie) korzystała z pomocy i ochrony pana dziedzicznego Karola Goczałkowskiego (zm. w 1676 roku), gromadzącego swoich poddanych w celu czytania ksiąg ewangelickich. Ze względu na brak źródeł trudno te fakty uszczegółowić; tym trudniej jest odpowiedzieć na pytanie, czy również przodkowie Karola Goczałkowskiego (wśród których na pewno ojciec Adam był protestantem) sprawowali opiekę nad poddanymi współwyznawcami, ułatwiając im w ten sposób trwanie w wierze ojców. Za- 
gadnieniem czekającym na swego badacza jest kwestia sprawowania w omawianym okresie w puńcowskiej parafii posługi duszpasterskiej. Jej poziom i zakres, a także osobiste przymioty kapłanów, umiejętność współpracy z ludźmi i charyzma musiały mieć niebagatelny wpływ na wybory moralne i religijne członków ówczesnej wspólnoty wiejskiej, ułatwiając (lub wręcz przeciwnie!) adaptację wiernych $\mathrm{w}$ zmieniającej się w połowie XVII wieku rzeczywistości.

Wskazany przeze mnie stan rzeczy nie tylko stabilizował w obu wioskach sytuację wyznaniową. Miał również wpływ na inne relacje społeczne, np. język, jakim się wówczas posługiwano. Lektura tekstów sprawozdań wizytacyjnych wskazuje jednoznacznie, że księża katoliccy celem zwiększenia skuteczności swoich działań przeprowadzali katechezy i głosili kazania w języku, którym posługiwali się wierni. W parafii puńcowskiej, jak i w zdecydowanej większości ośrodków leżących na terenie dawnego księstwa cieszyńskiego, był to język polski w jego lokalnej odmianie. Jak wynika z przeprowadzonych przez Idziego Panica badań, stan ten utrzymał się również w następnych stuleciach (Panic, 2016).

Obie społeczności (katolicka i ewangelicka) żyły w tym czasie najprawdopodobniej zgodnie i bez większych konfliktów, wchodząc nierzadko w sieć wzajemnych kontaktów. Zachodziły one głównie w sferze gospodarki wiejskiej oraz do pewnego stopnia w różnych relacjach rodzinnych. Dowodem na to są m.in. liczne w parafii małżeństwa międzywyznaniowe (uchwytne źródłowo od lat 90. XVII wieku). Kwestia ta jednak wykracza poza zakreślone ramy artykułu, zaś odpowiedź na szereg pytań badawczych z nią związanych wymaga podjęcia dalszych badań.

\section{Bibliografia}

\section{Źródła}

Al Saheb, J. i Pindur, D. 2008. Vizitačni protokoly vratislavské diecéze z roku 1697. Těšinské arcikněžství. Opava: Středisko pro vydávání historických pramenů.

Franek, J. 1939. Dzieje placówki jezuickiej w Cieszynie w okresie kontrreformacji [dysertacja doktorska. Maszynopis powielony znajduje się w Książnicy Cieszyńskiej]

Archiwum Państwowe w Katowicach. Oddział w Cieszynie [APC], zespół akt Komora Cieszyńska [KC], nr 2350, Grundregister der Gemeinden Dzingelow et Ober Lischna [1623-1756]. 
Jungnitz, J. 1904. Visitationsberichte der Diözese Breslau. Archidiakonat Oppeln. Erster Teil. Breslau: G.P. Aderholz Buchhandlung.

Archiwum parafii w Lesznej Górnej [APLG], nr 19, Nrus I. Liber Copulatorum, Baptisatoru[m] et Mortuorum Parochiae Lischnensis [...].

Panic, I. 1994. Sprawozdania wizytacyjne biskupów wrocławskich (z roku 1717). Dekanaty: cieszyński, frysztacki, frydecki, wodzisławski i bielski. Cieszyn: Polskie Towarzystwo Historyczne. Oddział w Cieszynie.

Szersznik, L.J. 2004. Materiały genealogiczno-heraldyczne do dziejów szlachty księstwa cieszyńskiego, wyd. W. Gojniczek. Cieszyn: Książnica Cieszyńska.

\section{Literatura przedmiotu}

Below, J. i Legendź, M. 2009. Leśne kościoły. Miejsca tajnych nabożeństw ewangelickich w Beskidzie Śląskim. Bielsko-Biała: Augustana.

Chlebowczyk, J. 1966. Gospodarka Komory Cieszyńskiej na przełomie XVII-XVIII oraz w pierwszej połowie XVIII wieku. Wrocław: Zakład Narodowy im. Ossolińskich, Wydawnictwo Polskiej Akademii Nauk.

Czyż, R., Gojniczek, W. i Spratek, D. red. 2010. Trzysta lat tolerancji na Ślasku Cieszyńskim. W trzystulecie założenia kościoła Jezusowego w Cieszynie. Cieszyn - Český Těšín: Parafia Ewangelicko-Augsburska, Śląski Kościół Ewangelicki Augsburskiego Wyznania w Republice Czeskiej.

Dudała, H. 2015. Clerus decanatus Plesnensis w świetle protokołów kongregacji dekanalnych pszczyńskich z lat 1691-1756. Edycja źródtowa. Katowice: UŚ, Archiwum Archidiecezjalne.

Kracik, J. 2011. Prawie wielebni. Kraków: Petrus.

Lewowicki, T. i Grabowska, B. red. 1996. Społeczności pogranicza - wielokulturowość - edukacja. Cieszyn - Warszawa: UŚ - Filia w Cieszynie, Wyższa Szkoła Pedagogiczna ZNP w Warszawie.

Lewowicki, T., Różańska, A. i Klajmon, U. red. 2002. Kwestie wyznaniowe w społecznościach wielokulturowych. Cieszyn: UŚ - Filia w Cieszynie.

Machej, A. 2000. Sytuacja religijna w Księstwie Cieszyńskim po restytucji kościoła katolickiego za panowania ostatnich Piastów. W: Budniak, J. i Rusek, H. red. Pojednajcie się... materiały z sesji naukowej „Pastoralny i społeczno-kulturowy wymiar ekumenizmu na Śląsku Cieszyńskim, Bielsko-Biała, 24-25.03.2000". Cieszyn - [Brenna: Józef Budniak], ss. [25]-68.

Maroń, F. 1972. Parafia górnośląska w pierwszym ćwierćwieczu XVIII w. Śląskie Studia Historyczno-Teologiczne. 5, ss. 151-225. 
Panic, I. i Zbylut-Jadczyk, K. red. 2018. Parafia w Puńcowie - od zarania do czasów wspótczesnych. Puńców: Parafia Rzymskokatolicka w Puńcowie.

Panic, I. 2010. Kościół w księstwie cieszyńskim. W: Panic, I. red. Dzieje Śląska Cieszyńskiego od zarania do czasów wspótczesnych. T. 2. Śląsk Cieszyński w średniowieczu (do 1528). Cieszyn: Starostwo Powiatowe, ss. 379-454.

Panic, I. 2011. Sytuacja religijna. W: Panic, I. red. Dzieje Ślaska Cieszyńskiego od zarania do czasów wspótczesnych. T. 3. Ślask Cieszyński w początkach czasów nowożytnych (1528-1653). Cieszyn: Starostwo Powiatowe, ss. 255-296.

Panic, I. 2016. Język mieszkańców Śląska Cieszyńskiego od średniowiecza do połowy XIX wieku. Cieszyn: Polskie Towarzystwo Historyczne. Oddział w Cieszynie.

Pilnáček, J. [k vyd. připravil Karel Müller]. 1991-[1998]. Rody starého Slezska. [Vyd. 2]. T. 4. Brno: Moravský zemský archiv.

Pindur, D. 2010a. Osudy evangelíků v Bystřici v období rekatolizace (1654-1709). Těśínsko, z. 4, ss. 1-8.

Pindur, D. 2010b. Století rekatolizace Těšínska. Ke konfesním proměnám. W: Czyż, R., Gojniczek, W. i Spratek, D. red. Trzysta lat tolerancji na Ślasku Cieszyńskim. W trzystulecie założenia kościoła Jezusowego w Cieszynie. Cieszyn - Český Těšín: Parafia Ewangelicko-Augsburska, Śląski Kościół Ewangelicki Augsburskiego Wyznania w Republice Czeskiej, ss. 89-129.

Spyra, J. 2012a. Dzieje polityczne. W: Panic, I. red. Dzieje Śląska Cieszyńskiego od zarania do czasów wspótczesnych. T. 4. Śląsk Cieszyński w okresie 1653-1848. Cieszyn: Starostwo Powiatowe, ss. 13-120.

Spyra, J. 2012b. Stosunki wyznaniowe. W: Panic, I. red. Dzieje Śląska Cieszyńskiego od zarania do czasów wspótczesnych. T. 4. Ślask Cieszyński w okresie 1653-1848. Cieszyn: Starostwo Powiatowe, ss. 283-340.

Šmerda, M. 2004. Kněžna Alžběta Lukrecie a protireformace na Těšínsku. Těšínsko. 4, ss. 1-10.

\section{From the studies on the origin of religious transformations in Cieszyn Silesia at the beginning of the Counter-Reformation - the case of the parish in Punców near Cieszyn}

Abstract: A multidenominational image of Cieszyn Silesia is one of the elements forming the character of the borderland. This raises the question of the genesis of this phenomenon. An attempt to capture it was made using an example of 
two selected villages - Dzięgielów and Puńców, which are part of the parish in Puńców and in the discussed period were in the hands of two different owners. The visitation report analysis, prepared for the needs of the church administration in the second half of the seventeenth and the beginning of the eighteenth century, leaves no doubt that in the process of shaping the denominational map of these places, the decisive role was played by the confession and religious commitment of specific owners of the goods.

Keywords: Cieszyn Silesia, Modern Ages, nobility, re-catholisation, Puńców, Dzięgielów

Translated by Aleksandra Jadczyk 